\title{
METHODOLOGICAL BASIS FOR RESEARCH ON THE RELATIONSHIP BETWEEN ENVIRONMENTAL INITIATIVES AND BUSINESS COMPETITIVENESS
}

Barbara Fura, PhD (ORCID: 0000-0002-9601-6634) - University of Rzeszów

Correspondence address:

Ćwiklińskiej Street 2, 35-601, Rzeszów, Poland

e-mail:bfura@ur.edu.pl

ABSTRACT: This article presents a methodological basis of the project "Environmental Initiatives and Factors of Competitiveness in Companies" with reg. no. 2016/23/D/HS4/03007. The project is funded by the National Science Centre as a part of the SONATA 12 Contest. The aim of the project is to determine the relationship between environmental initiatives and the competitiveness of companies. Both primary and secondary statistical data was used for the project. This article describes the main project assumptions, research thesis, manner of acquiring the empirical data and statistical analysis of such data. The attention was also paid on difficulties and limitations which occurred when conducting the research.

KEY WORDS: environmental initiatives, factors of competitiveness, companies 


\section{Introduction}

The effectiveness of scientific research is determined by proper preparation and implementation of the research project. Each research project, irrespective of the scientific problem to be solved, should consist of specific elements. Apart from the research problem, defined on the basis of the review of literature, they also include a scientific aim of the project, a concept, research theses/hypotheses, a research plan, methodology and a cost estimate. When implementing a research project, the researcher must answer the following questions: what to research, how to research and why is the problem raised by the researcher important?

It is also essential for the project to have a theoretical underpinning, and its results should fill the gap in knowledge or extend the current knowledge. Thus, the project has the chance to develop a specific scientific field and a scientific discipline. Apart from the theoretical contribution to such development, the research project should also have an application value.

The aim of this article is to present the methodological basis of the project: "Environmental Initiatives and Factors of Competitiveness in Companies" as exemplary research conducted throughout Poland into a representative sample.

\section{Subject and main assumptions of the project}

Business activities of companies bring economic growth and development which stimulate the creation of new technologies, an increase in income and improvement of the quality of life of societies (Stec et al., 2014, p. 505). Innovative, resource-saving manufacturing methods and techniques are developed, and the growth in income of societies supports the increase of demand for services provided by the natural environment (Tisdell, 2001, p. 190).

Apart from the beneficial effect on the social and economic growth and development, the quality of life, innovation level and on the development of new knowledge and technology, the broadly understood progress has also a dark side. It manifests itself in the polarisation of societies, in the phenomenon of exclusion as well as in natural environment pollution. The excessive pressure on the environment causes, inter alia, in global climatic changes, the degradation of the ozone layer, acid rains and the degradation of drinking water resources (Czaja, Becla, 2011, p. 26). In order to prevent such changes, pressure is put on business entities to limit their adverse effects on the broadly understood surroundings. The legal restrictions, norms, orders and bans issued against active business entities initially were a heavy burden for 
them as they constituted, above all, an additional expense. Over time, test results have shown that although the compliance with environmental regulations pushes up additional costs, the companies may, however, decrease their costs in other areas of their activities (e.g. Saxena, Khandelwal, 2012, p. 555; Stanwick, Stanwick, 1998, p. 195-197).

\section{Research gap, aim and thesis}

With the changing attitude of companies to the issues concerning natural environment protection, there appears a question about whether a company may improve its competitiveness through undertaking activities for the benefit of natural environment protection (Riillo, 2017, p. 626-627). Such a problem has not been widely examined so far, especially in Polish literature. What is more, in the literature concerning this subject there is no consensus or clear indication about a possible mechanism which would lie at the root of such an interaction (Kudłak, 2010; Li et al., 2019).

The presented research fills the research gap by diagnosing the interaction between environmental activities of companies and their competitiveness. In the study, competitiveness was measured through its priorities/factors (Awwad et al., 2013, p. 71) including quality, delivery, flexibility and costs. Such priorities are understood as dimensions of the company production system necessary to meet the requirements of the market in which the company competes. Quality means a low rate of product defects, reliability of operation, compliance with standards and a low level of harmfulness/no harmfulness to the natural environment. Delivery is an issue connected with time. It describes how quickly the product is supplied to the client. Flexibility means the ability of the production system to adjust to changes in designing and planning the production volume and diversity. Costs represent the ability to effectively manage production costs.

The research takes into account (Leoński, 2016, p. 46-53; Schoenherr, 2012, p. 116-128) activities undertook for the benefit of environmental protection/initiatives such as pollution prevention (i1), material recycling (i2), reduction of produced waste (i3), reduction of fuel and energy consumption (i4) and reduction of water consumption (i5).

The aim of the research was to describe the relationship between environmental initiatives and factors of competitiveness in companies, taking into consideration qualitative and quantitative features of companies and the level of the social and economic development of Polish macroregions. The research results allowed to verify the research thesis: 
T: The relationships between environmental initiatives and factors of competitiveness in companies are determined by the social and economic development level of the Polish macroregions and qualitative and quantitative features of the companies. This thesis is a generalization of four research hypotheses verified in the project.

The theoretical frames of the research were determined by a resourcebased view of the firm (RBV) represented mainly by Barney (1991). The research considers environmental initiatives as potentially valuable, rare, inimitable and non-substitutable (VRIN) resources. The diverse effect of the influence of environmental initiatives on competitiveness priorities was substantiated based on the theory of performance frontiers (TPF) by Schmenner and Swink (1998).

Both secondary and primary statistical data had to be applied to achieve the research aim and to verify the research thesis.

\section{Methods of acquiring and analyzing primary data}

The research was nationwide. When selecting the territorial area of the research, the intention was to conduct comprehensive research which would enable international comparisons. The research covered companies from seven macroregions of Poland, i.e. southern, north-western, south-western, northern, central, eastern and Masovian Voivodeship macroregions according to the NUTS 1 division in Poland, as valid from 1.01.2018 (Regional Statistics, 2018).

The statistical population included 21317 entities conducting business operations which as of 21.01.2018 were classified in the Emerging Markets Information Service (EMIS, 2018) in the production sector (31 according to the North American Industry Classification System - NAICS). For the abovementioned statistical population, the minimum size of the sample was assessed to include 1016 entities (Sample Size Calculator, 2018). The sample which was representative due to the number of companies registered in the macroregions was drawn by using an on-line generator of random numbers (Random Number Generator, 2018). The response rate was 76.8\%.

The necessary primary data which came from own research was obtained on the basis of a research tool - questionnaire. Exemplary surveys using a questionnaire, survey form/interview and concerning environmental activities of companies are available, inter alia, in (Hadryjańska, 2015, p. 442-448; Rojek-Nowosielska, 2017, p. 189-195; Schoenherr, 2012, p. 126). The companies assessed their degree of involvement in environmental initiatives according to the Likert scale with values from 1 to 5 , where 1 - a very low 
degree of involvement, 5 - a very high degree of involvement. Similarly, the companies assessed their performance concerning the above-mentioned competitiveness priorities. Quality was described though variables: product characteristics, product efficiency, perceived general product quality; delivery was described through the assessment of its conditions concerning order placement efficiency, time of supply, conformity of products to the order; flexibility - through the flexibility of supply, flexibility in changing the production volume, flexibility in offer adjustment; costs - through direct manufacturing costs, total production costs of materials for production and costs of environmental protection.

Just like in case of environmental initiatives, the five categories of the Liker scale were also used to assess the degree of company investment in competitiveness factors $(1-$ a very low degree of investment, 5 - a very high degree of investment). The research was conducted mainly by applying computer-assisted telephone interviewing (CATI). Some companies took part in the survey by filling in on-line questionnaires (Questionnaire survey, 2018) or questionnaires in a paper version.

The empirical analysis of the primary data was based on Mann-Whitney and Kruskal-Wallis tests. The Mann-Whitney test is a non-parametric equivalent of the Student's t-test applied in case of two comparative groups, and the Kruskal-Wallis test is a non-parametric equivalent of a variance analysis applied in case of three or more groups (Aczel, 2000, p. 716-719). Unlike their parametric equivalents, the tests do not require many restrictive assumptions (Jóźwiak, Podgórski, 2012, p. 280).

The above-mentioned tests were used in the research to diagnose various degrees of involvement of companies in the above-mentioned environmental initiatives, depending on company features such as export (yes/no), ISO 14001 (yes/no), ISO 9001 (yes/no), company size, Polish Classification of Activities (PKD), territorial area of conducting activities, origin of company capital. If the Kruskal-Wallis test was significant, then a post hoc analysis was used additionally to indicate different groups (Stanisz, 2006, p. 386).

As the next step, dependencies between qualitative variables were analyzed on the basis of a chi-squared test. When making decisions in the chisquared test, the right-tailed critical region was taken into account $\left(\chi^{2} \geqslant \chi_{\alpha}^{2}\right)$. Statistics $\chi_{\alpha}^{2}$ is a critical value read from the chi-squared distribution table for the assumed significance level $\alpha$ and for $(r-1)(s-1)$ of the degrees of freedom, where $r$ is the number of options of the first feature and $s$ - the number of options of the second feature. The calculated value of the test statistics $\chi^{2}$ is comparable to the critical value $\chi_{\alpha}^{2}$ and if the inequality $\chi^{2} \geqslant \chi^{2}{ }_{\alpha}$ is true, for the assumed significance level $\alpha$, the null hypothesis $\left(H_{0}\right.$ : the tested features are independent) is rejected in favour of the alternative hypothesis 
( $H_{1}$ : the tested features are not independent). But in case of the opposite inequality $\left(\chi^{2}<\chi_{\alpha}^{2}\right)$, there exist no grounds for rejecting $H_{0}$, which means that the tested features are independent (Jóźwiak, Podgórski, 2012, s. 337).

To measure the strength of the above-mentioned dependencies, Cramer's $\mathrm{V}$ was used. It is a normed and dimensionless quantity with values between $[0,1]$. If the value of Cramer's $V$ is 0 , then there is no dependence between the features, if $V=1$, the features are dependent. The closer to the unity Cramer's $\mathrm{V}$ is, the stronger the dependence is.

The scope of testing features on weakest scales may be extended to include the results of the correspondence analysis. Its good point is the possibility to show a clear, graphic presentation of the co-existence of variable categories. It is possible thanks to marking points which depict feature categories on one-, two- and three-dimensional coordinate systems, and as little as possible information about the actual structure of relationships is lost (Stanimir, 2008, p. 337-338).

The correspondence analysis has two variants, i.e. a simple correspondence analysis and a multiple or multivariable correspondence analysis. The simple correspondence analysis serves for visualization of relationships between two nominal features included in the form of a contingency table. The simple correspondence analysis may be expanded by the multiple correspondence analysis, which is used for the analysis of more than two nominal features (Górniak, 2000, p. 117). The correspondence analysis was applied for clarifying statistically significant dependencies between the level of involvement of companies in preventing pollution (i1) and material recycling (i2), and the financial situation of companies (good/bad situation).

It was assumed in the research that both environmental initiatives and factors of competitiveness are latent (non-observable) variables. A latent variable is a variable which has no established indirect measure procedures and is measured directly through observable indicators (Sagan, 2000, p. 53). Structural equation modelling (SEM) was used to build the model indicating the influence of environmental initiatives on factors of competitiveness in companies.

The role of the dependent variable was fulfilled by factors of competitiveness in companies, and the role of the independent variable was fulfilled by environmental initiatives (i1-i5). Before the analysis, the reliability of measurement scales which measure specific factors of competitiveness (quality, delivery, flexibility and costs) and environmental initiatives (i1-i5) were verified by using Cronbach's $\alpha$.

Due to the lack of the multivariate normal distribution of pointer variables and the application of ordinal variables to assess the models of confirmatory factor analysis (CFA) and output structural models, the diagonally 
weighted least squares (DWLS) method was applied (French, Finch, 2015, pp. 60-62). The necessary calculations were made in the $\mathrm{R}$ non-commercial program (R Core Team, 2016).

The degree of the adjustment of theoretical models to empirical data was assessed through a series of both absolute measures (e.g. statistics $\chi^{2}$, root mean square error of approximation (RMSEA), (standardized) root mean square residual ((S)RMR)) and relative measures (e.g. (non) normed fit index ((N)NFI), comparative fit index (CFI)) (Januszewski, 2011, p. 240-241; Konarski, 2009, p. 345-357).

The application of the CFA allowed deciding on the structure of the resultant assessed model. However, when building structural models, it should be remembered that the starting point should always be a theory concerning the surveyed phenomenon (French, Finch, 2015, p. 60-62). It allows us to avoid errors in the model specification, which are hard to be corrected (Bedyńska, Książek, 2012, p. 162). It is the theory which is the basis for determining the variables taken into account in the model and for dependencies occurring between them.

\section{Methods of acquiring and analyzing secondary data}

Two types of secondary data were used in the research. One of them was pointer variables characterizing the social and economic situation of Polish macroregions in the year 2017. The source of data about the macroregions was public statistics (GUS, 2017; GUS, 2018a; GUS, 2018b). When surveying into the level of macroregion development, the following areas were taken into consideration (Borys, 2014, p. 14): 1. Demography, labour market, population income, 2. Technical infrastructure and environmental protection, 3. Social infrastructure, 4. Agriculture and forestry, 5. Entrepreneurship, innovations, R\&D. The areas were represented by a total of 51 features which were initially selected using in the first place the criterion of sufficient variation of features. At that stage, 19 variables whose variation level was lower than $10 \%$ were rejected. The remaining variables were put through correlation verification which was conducted on the basis of the inverse correlation matrix (Młodak et al., 2016, p. 4-5). The application of such a method resulted in a rejection of the next 7 features. Finally, a set of 25 features were obtained, and they included stimulants (21 variables) and destimulants (4 variables).

Such variables were used to determine the synthetic measure, which expresses the level of macroregion development in each of the above-mentioned areas of development. An arithmetic mean of the synthetic measures of each area gave the final measure of the level of macroregion development. The synthetic measures in the areas 1-5 were determined by using a stand- 
ard method suggested by Z. Hellwig (1968) and the zero unitarization method (Kukuła, 2012). Both the methods belong to a group of multivariate methods called a multivariate comparative analysis (MCA). The MCA enables analysis of complex objects and phenomena, i.e. when many features (variables) and factors have an influence on the state and behaviour of such objects and phenomena at the same time (Bąk, 2016, p. 24).

The method proposed by Z. Hellwig includes the determination of the taxonomic distance from the standard, which is an abstract unit having the most favourable values of each of the features. Specific stages of the standard development method were included in the following points (Bąk, 2016, p. 26; Stec, 2017, p. 72-73; Malina, 2004, p. 73):

1. Creation of the observation matrix of diagnostic features.

2. Normalization (standarization) of features.

3. Determination of the abstract object (development standard).

4. Determination of a distance from the standard for each object.

5. Determination of the arithmetic mean of the Euclidean distance.

6. Determination of the synthetic measure of development.

The development measure achieves values ranging $[0,1]$. The closer to the unity the measure values the more closely they are to the standard the assessed object is, i.e. the higher position has the object (macro-region) in the ranking.

The zero unitarization method, just like the standard development method by Z. Hellwig, is a comparison of many objects through selected criteria. The criteria may be expressed through various quantities (Kościółek, 2015 , p. 195). The aim of the zero unitarization method is to normalize the examined criteria.

Normalization of variables is based on formulas:

for stimulants:

for destimulants:

$$
z_{i j}=\frac{x_{i j}-\min _{i}\left\{x_{i j}\right\}}{R_{j}}
$$

$$
z_{i j}=\frac{\max _{i}\left\{x_{i j}\right\}-x_{i j}}{R_{j}}
$$

where is a range calculated from the following formula:

$$
R_{j}=\max _{i}\left\{x_{i j}\right\}-\min _{i}\left\{x_{i j}\right\}
$$


The unitarization formulas ensure a varied variance and, also a constant range of normalized values of all features. The synthetic measure, according to the zero unitarization method, is calculated as an arithmetic mean of normalized values of diagnostic features. The synthetic development measure determined in this way, just like the $\mathrm{Z}$. Hellwig's measure, has values ranging $[0,1]$.

In the next stage of the procedure of the macroregion development assessment, the concordance of the results obtained using both the methods was analyzed. In order to compare the concordance of the synthetic measure values, the Pearson correlation coefficient was used and to compare the concordance of the obtained rankings, the Spearman's rank correlation coefficient was used (Bąk, 2016, p. 29).

The second type of secondary data used in the research is financial data from financial statements of the companies which are available in the EMIS base. In this way, information about liquidity, profitability, debt level and business efficiency was obtained, and then the financial situation of the companies in the years 2012-2017 was assessed. Such an assessment was made by using the E. Mączyńska discriminant function.

Just like other accessible discriminant models, such a function, thanks to the aggregation of various financial ratios which are assigned with weights expressing the role of a given variable in the synthetic resulting figure, enabled the division of the companies into entities having a good or bad financial situation (Bombiak, 2010, p. 145). The function has the following form (Mączyńska, 1994, p. 46-49):

$$
Z M=1,5 X_{1}+0,08 X_{2}+10,0 X_{3}+5,0 X_{4}+0,3 X_{5}+0,1 X_{6} \text { ， }
$$

where:

$\mathrm{X}_{1}$ - (gross profits+depreciation)/liabilities and provisions for liabilities,

$\mathrm{X}_{2}-\quad$ assets/liabilities and provisions for liabilities,

$\mathrm{X}_{3}-\quad$ gross profits/assets,

$\mathrm{X}_{4}-\quad$ gross profits/sales revenues,

$\mathrm{X}_{5}-\quad$ inventory/sales revenues,

$\mathrm{X}_{6}-\quad$ sales revenues/assets.

$Z M \leq 0$ means that the company is in danger of bankruptcy and $Z M \in(0,1)$ means that the company has a poor financial situation but is not in danger of bankruptcy. If $Z M \in[1,2]$ it means that the company has a good financial situation. And if $Z M>2$, then the company is in a very good financial condition. 


\section{Conclusions}

The assumed procedures of gathering and analyzing primary and secondary data allowed to create a database which was used to make reliable statistical analyzes. Ensuring the representativeness of the sample allowed to generalize the obtained results to the whole statistical population, i.e. manufacturing companies in Poland.

The research confirmed the influence of environmental initiatives on the competitiveness of companies. Such an influence depended mainly on the financial situation of the companies and on the level of macroregion development as well as on the selected features of the companies. A greater effect in terms of the influence of environmental initiatives on the improvement of the factors of competitiveness was observed in companies located in macroregions which are worse developed than in companies from macroregions which are better developed. Benefits from environmental initiatives also depended on the financial situation of the companies. Entities in a better financial situation may expect a greater effect in the form of improvement of competitiveness than entities which are in a bad situation.

The competitiveness improvement in terms of the quality of produced goods offered supply conditions, the flexibility of production and manufacturing costs are observed to a greater extent in companies operating on a larger territorial area, in companies with mostly external capital and in exporters.

This article is an example of a research project which may be useful to people preparing concepts of own research original scientific projects. However, the presented tests are not free from limitations. Firstly, to measure the degree to which the company is involved in initiatives and to determine the significance of competitiveness priorities, opinions of the companies were taken into account. For both the measures most companies assessed themselves well or very well. A small number or even lack of negative assessments casts doubt on the reliability of the assessments. Also, such a lack of poor assessments made it difficult to fully verify the advanced thesis.

\section{Acknowledgements}

This research has been supported by the National Science Center within the framework of the project No. 2016/23/D/HS4/03007 Environmental initiatives and competitive factors of enterprises. 


\section{References}

Aczel, A.D., 2000. Statystyka w zarządzaniu. Pełny wykład. Wydawnictwo Naukowe PWN, Warszawa.

Awwad, A.S., Khattab, A.A., Anchor, J.R., 2013. Competitive Priorities and Competitive Advantage in Jordanian Manufacturing. Journal of Service Management, 6(1), 69-79, https://doi:10.4236/jssm.2013.61008.

Barney, J., 1991. Firm Resources and Sustained Competitive Advantage. Journal of Management, 17(1), 99-120, https://doi.org/10.1177/014920639101700108.

Bąk, A., 2016. Porządkowanie liniowe obiektów metodą Hellwiga i TOPSIS - analiza porównawcza. Prace Naukowe Uniwersytetu Ekonomicznego we Wrocławiu, 426, 22-31, https://doi:0.15611/pn.2016.426.02.

Bedyńska, S., Książek, M., 2012. Statystyczny drogowskaz 3. Praktyczny przewodnik wykorzystania modeli regresji oraz równań strukturalnych. SWPS, Warszawa.

Bombiak, E., 2010. Modele dyskryminacyjne jako metoda oceny sytuacji finansowej przedsiębiorstwa. Zeszyty Naukowe Akademii Podlaskiej w Siedlcach. Seria: Organizacja i Zarządzanie, 86, 141-152.

Borys, T., 2014. Wybrane problemy metodologii pomiaru nowego paradygmatu rozwoju - polskie doświadczenia. Optimum. Studia Ekonomiczne, 3(69), 3-21.

Central Statistical Office (GUS), 2017. Statistical Yearbook of Industry - Poland, Warszawa.

Central Statistical Office (GUS), 2018a. Statistical Yearbook of the Regions - Poland, Warszawa.

Central Statistical Office (GUS), 2018b. Polish Regions, Warszawa.

Czaja, S., Becla, A., 2011. Czterech jeźdźców ekologicznej zagłady we współczesnym świecie. In: Kryk, B. (Ed.), Trendy i wyzwania zrównoważonego rozwoju. Wydawnictwo Zapol, Szczecin, 35-49.

Emerging Markets Informative Service (EMIS), https://www.emis.com/php/companies/quick-screener/screener?subp= [21-01-2018].

French, B.F., Finch, W.H., 2015. Latent Variable Modeling with R. Routledge, New YorkLondon.

Górniak, J., 2000. Zastosowanie analizy korespondencji w badaniach społecznych i marketingowych. ASK, 9, 115-134.

Hadryjańska, B., 2015. Ekologizacja procesu produkcji a kształtowanie konkurencyjności w przedsiębiorstwach przetwórstwa mleczarskiego. PTE Oddział w Poznaniu, Poznań.

Hellwig, Z., 1968. Zastosowanie metody taksonomicznej do typologicznego podziału krajów ze względu na poziom rozwoju oraz zasoby i strukturę wykwalifikowanych kadr. Przegląd Statystyczny, 15(4), 307-326.

Januszewski, A., 2011. Modele równań strukturalnych w metodologii badań psychologicznych. Problematyka przyczynowości w modelach strukturalnych i dopuszczalność model. Studia z Psychologii w KUL, 17, 213-245.

Jóźwiak, J., Podgórski, J., 2012. Statystyka od podstaw. PWE, Warszawa.

Konarski, R., 2009. Modele równań strukturalnych. Teoria i praktyka. Wydawnictwo Naukowe PWN, Warszawa. 
Kościółek, M., 2015. Wykorzystanie analizy wielowymiarowej do badania zróżnicowania potencjału innowacyjnego Polski. Metody Ilościowe w Badaniach Ekonomicznych, 16(3), 194-201.

Kudłak, R., 2010. Wpływ ochrony środowiska na konkurencyjność. Gospodarka Narodowa, 1-2, 109-125.

Kukuła, K., 2012. Propozycja budowy rankingu obiektów z wykorzystaniem cech ilościowych oraz jakościowych. Metody Ilościowe w Badaniach Ekonomicznych, 13(1), 6-13.

Leoński, W., 2016. Ekologiczne aspekty społecznej odpowiedzialności biznesu. Studia i Prace WNEiZ US, 43(1), 46-53, https://doi:10.18276/sip.2016.43/1-04.

Li, G. et al., 2019. How green technological innovation ability influences enterprise competitiveness. Technology in Society, 59, https://doi.org/10.1016/j.techsoc. 2019.04.012.

Malina, A., 2004. Wielowymiarowa analiza przestrzennego zróżnicowania struktury gospodarki Polski według województw. Wydawnictwo Akademii Ekonomicznej w Krakowie, Kraków.

Mączyńska, E.,1994. Ocena kondycji przedsiębiorstwa (Uproszczone metody). Życie Gospodarcze, 38, 42-45.

Młodak, A., Józefowski, T., Wawrowski, Ł., 2016. Zastosowanie metod taksonomicznych w estymacji wskaźników ubóstwa. Wiadomości Statystyczne, 2(657), $1-24$.

Questionnaire survey, https://goo.gl/forms/wthVpMI1DhMjcx132 [15-02-2018].

R Core Team, 2016. R: A language and environment for statistical computing. R Foundation for Statistical Computing, Vienna, Austria, https://www.R-project.org/

Random Number Generator, https://generujemy.pl/losowa_liczba [25-01-2018].

Regional Statistics, https://stat.gov.pl/statystyka-regionalna/jednostki-terytorialne/ klasyfikacja-nuts/klasyfikacja-nuts-w-polsce/ [03-01-2018].

Riillo, C.A., 2017. Beyond the question "Does it pay to bee green?": How much green and when? Journal of Cleaner Production, 141(10), 626-640, https://doi. org/10.1016/j.jclepro.2016.09.039.

Rojek-Nowosielska, M., 2017. Społeczna odpowiedzialność przedsiębiorstw. Model-diagnoza-ocena. Wydawnictwo Uniwersytetu Ekonomicznego we Wrocławiu, Wrocław.

Sagan, A., 2000. Wybrane problemy identyfikacji i pomiaru struktur ukrytych. Zeszyty Naukowe Akademii Ekonomicznej w Krakowie, 54, 53-64.

Sample Size Calculator, https://www.naukowiec.org/dobor.html [20-01-2018].

Saxena, R.P., Khandelwal, P.K., 2012. Greening of industries for sustainable growth: An exploratory study on durable, non-durable and services industries. International Journal of Social Economics, 39(8), 551-586, http://dx.doi.org/10.1108/ 03068291211238437.

Schmenner, R.W., Swink, M.L., 1998. On the theory in operations management. Journal of Operations Management, 17(1), 97-113, https://doi.org/10.1016/S02726963(98)00028-X.

Schoenherr, T., 2012. The role of environmental management in sustainable business development: A multi-country investigation. International Journal of Production Economics, 140(1), 116-128, https://doi.org/10.1016/j.ijpe.2011.04.009. 
Stanimir, A., 2008. Wykorzystanie analizy korespondencji w badaniach marketingowych. Zastosowania metod statystycznych w badaniach naukowych. StatSoft Polska, Kraków.

Stanisz, A., 2006. Przystępny kurs statystyki z zastosowaniem STATISTICA PL na przykładach z medycyny, t. 1: Statystyki podstawowe. StatSoft Polska, Kraków.

Stanwick, P.A., Stanwick, S.D., 1998. The Relationship Between Corporate Social Performance, and Organizational Size, Financial Performance, and Environmental Performance: An Empirical Examination. Journal of Business Ethics, 17, 195-204.

Stec, M., 2017. Taksonomiczna analiza poziomu rozwoju społeczno-gospodarczego województw Polski. Studium przypadku - województwo podkarpackie. Wydawnictwo Uniwersytetu Rzeszowskiego, Rzeszów.

Stec, M. et al., 2014. Socio-Economic Development in the EU Member States - Concept and Classification. Engineering Economics, 25(5), 504-512, http://dx.doi.org/ 10.5755/j01.ee.25.5.6413.

Tisdell, C., 2001. Globalization and sustainability: environmental Kuznets curve and the WTO. Ecological Economics, 39, 185-196, https://doi.org/10.1016/S09218009(01)00234-8. 